\title{
Mabruchismo: concubinage and colonial power in Italian Libya (1911-1932)
}

\author{
Andrea Tarchi* \\ Faculty of Law, Vrije Universiteit Amsterdam, Netherlands
}

(Received 8 February 2021; revised 12 April 2021; final version accepted 20 April 2021)

\begin{abstract}
This article assesses the Liberal and Fascist administrations' shifting attitudes towards colonial concubinage during the years of the repression of the anti-colonial resistance in Italian Libya (1911-32). Also known as mabruchismo, concubinage in Libya closely resembled its counterpart in Italian Eastern Africa, as it involved middle- to upper-class Italian officers coercing colonised women into engaging in often exploitative intimate relationships. During the first 20 years of colonisation of the territory, the colony's military administration employed an ambiguous stance regarding the practice, condemning it discursively to ingratiate itself with the local elites while unofficially allowing it to provide safe sex to its officers. When the resistance was defeated in the early 1930s, and the Fascist administration began its demographic colonisation plans, colonial concubinage was prohibited as out of place in a racially segregated settler colony. This article employs an analysis of official archival sources to trace the regulatory framework that shaped the lives of the Libyan women and Italian officers engaged in concubinage in a shifting colonial society. The colonial administrations" regulatory efforts toward colonial concubinage testify to the crucial role that Libyan women and racially "mixed" relationships played in shaping categories of race, class, and gender relative to the Italian colonial context.
\end{abstract}

Keywords: colonial concubinage; Libya; Italian colonialism; Fascism; military; sexuality; race.

\section{Introduction}

It is May 1924, and the anti-colonial resistance in the interior of Cyrenaica, in modern-day Libya, is still raging even though Italian troops have secured the coasts of the region more than 12 years before. In an effort to boost the military efforts against the Cyrenaican militias, the Italian King Vittorio Emanuele III signs royal decree no. 983, effectively increasing the deployment of troops to the Northern African colony. ${ }^{1}$ Article 3 of the decree states a mandate that clarifies the stance of the Italian government regarding the intimate life of its deployed officers:

The reserve officers [that will be sent to Cyrenaica] who have a wife will have to explicitly commit themselves to leave their families in Italy for the whole duration of their stay in the colony. ${ }^{2}$

The decree clarifies the Italian Fascist government's decision to bar intimate Italian partners of the army's male members in the colony. As shown throughout this article, the implications of this decree and other similar ones that preceded it would impact the very foundations of the relationship between the colonising power and the colonised society. As no Italian female partners were allowed in the colony, the colonial officers directly engaged with Libyan women and,

\footnotetext{
*Email: a.tarchi@vu.nl
} 
consequently, with Libyan society's patriarchal structures, since the first years of the colonial power's presence in the region. ${ }^{3}$ The intimate colonial encounter that defined the first 20 years of the Italian presence in Libya, characterised by a mainly military male Italian population engaging in intimate relationships with local women, exemplified the central role of gender and sexuality in the construction of racialised colonial boundaries.

Any assessment of the interactions and struggles between colonising powers and colonised populations involves the figure of the colonised woman, whose body represented the site on which colonial boundaries were produced and negotiated. Colonised women were often the subject of patriarchal protection by the colonised society while being discursively turned into sexualised objects by colonising powers. The centrality of the colonised woman's figure in colonial power relations is further embodied by the regulation of 'mixed' intimacies. ${ }^{4}$ Sexuality embodied the central field where the construction of gender, race, and class categories unfolded in the colonial political economy, while 'mixture' represented the very category that confused such classifications, making their construction apparent. In colonial settings, one of such classifications, gender, bespoke both 'a primary way of signifying relationships of power' (Scott 1986, 1067) and a frontier in which the construction of colonial categories and practices developed accordingly. For this reason, the study of the regulation of sexuality, and in a particular way of 'mixed' intimacies, is central to understanding how colonisers and colonised populations struggled for the creation of meanings related to colonial societies.

This article attempts to provide further insight into the regulation of sexuality and 'mixture' in the Italian colonial context, particularly in the Libyan colony, where the role of the regulation of 'mixed' intimacies has never been fully assessed. In particular, this article investigates how the Italian military colonial administrators regulated concubinage relationships (known as ' $m a b r u$ chismo' in Libya) between middle- to upper-class Italian officers and Libyan women during the first two decades of the Italian presence in the region (1911-32) when the colony was still heavily militarised due to a strenuous anti-colonial resistance. ${ }^{5}$ The inclusion of the Libyan context within a broader analysis of the regulation of 'mixture' in the Italian colonies is intended to further the academic debate on how central such liaisons were in the development of the gendered and racial categories inherent to Italian colonial societies.

Providing sexual relationships for armies deployed in colonial contexts has always been a major concern of military administrations. As explained by Bryder $(1998,815)$, 'the general belief persisted that men, particularly soldiers, required an outlet for their (hetero)sexual energies and that the army must provide them with "safe" sex.' One such 'outlet,' provided to upper-class officers who ought not to intermingle with lower-class troopers in non-segregated brothels, was colonial concubinage. Concubinage was widespread throughout colonies on different continents and at different times. The cases of concubinage studied in the contexts of Dutch (Ming 1983, Stoler 2002), Spanish (McKinley 2014), and English (Ballhatchet 1980, Hyam 1986) colonies are just some examples of the scholarship that testify how diffuse the practice was. As for the Italian context, much has been written on madamato, the concubinage relationships between Italian officers and Eastern African women. From its inception and inclusion in juridical (Sòrgoni 1998) and colonial discourse (Iyob 2000; Campassi 1987), to the role it played in shaping public and private spheres in the colony (Barrera 2004) and the agency it provided colonised women (Ponzanesi 2012), concubinage in Eritrea is an extensively researched topic. Moreover, recent works (Trento 2011) have also included the Ethiopian context into the broader debate over concubinage in the Italian colonies.

However, the same cannot be said about Italian Libya, where the study of 'mixed' intimacies and sexuality is still at its early stages, with the notable recent efforts provided by Yeaw and 
Spadaro (Yeaw 2018a; Yeaw and Spadaro 2020). The dissertation of Yeaw and the volume she edited alongside Spadaro were focused on highlighting Libyan women's voices and experiences as agents of anti-colonial resistance while removing them from 'the margins of nationalist and colonial narratives' (Yeaw 2018b, 3). This article attempts to build on these recent works while focusing on the power structures that framed Libyan women's experience under Italian colonial rule: namely, how the Italian colonial administration reacted to their intimate relations with Italian officers both discursively and practically. By doing so, this article aims to shed further light on Italian colonial discourse and practices regarding intimacy and racial 'mixture,' and therefore on how shifting conceptions of racial purity and colonial prestige were directly influenced by the regulation of Libyan women's bodies.

This article draws on sources from Italian state archives to trace the shifting attitudes, discourses, and policies that Italian colonial governments adopted toward Libyan women and their relationships with Italian officers, from the invasion of the territory in 1911 until the colonisers claimed complete control of the territory in 1932. It does not account for the couples' experiences themselves nor the agency of Libyan women. Almost all concubinage relationships in Libya were framed along intersectional lines of discrimination and exploitation, as was usual for any form of colonial 'mixed' intimacy. Unfortunately, official Italian sources tell us nothing about the experiences of the women who engaged in forms of mabruchismo themselves. Hence, it is beyond this article's scope to ascertain the agency and emotional role that they indeed must have played. However, this article accounts for the structural relations of power that shifted in reaction to them and actively shaped and transformed colonial assumptions regarding class, gender, and race. By analysing Italian military elites' speeches, internal orders to the army ranks, military circular letters, and official legislation, this article maps the Italian administrations' shifts in attitude toward Libyan society and its private sphere before the colony transitioned from a militarised space to being the object of state-sponsored demographic colonisation.

The article is structured in three main sections that will follow the historical development of the regulation of 'mixed' concubinage in Libya. The first section details how the first Italian administrations negotiated jurisdiction over the Libyans' private sphere with the local elites by condemning concubinage discursively while allowing it in practice. The second section traces the inconsistencies between discourse and practice over the regulation of 'mixture' that characterised weak Italian colonial administrations during the repression of the anti-colonial resistance. Finally, the third section maps the regulatory shift that accompanied the transition of Italian Libya from a militarised space to a settler colony, which saw the implementation of racial segregation policies that prohibited 'mixed' concubinage. In conclusion, this article argues that the regulation (or lack thereof) of concubinage in Libya followed the specific needs of the colonisers' political agenda, either drawing or erasing boundaries according to the colonial administrators' ideological and strategic needs.

\section{'Proper restraint towards the natives': the Italian discursive stance towards Libyan women in the first years of colonisation}

On 9 October 1911, the very same day the invading Italian army secured the perimeter of the city of Tripoli after one week of battle with the Libyan and Ottoman troops, the commander-in-chief Carlo Caneva issued the following circular order to all Italian troops and officers:

The Arab has a lively and profound religious sentiment and is a strict observant of his religious practices, which are quite different from ours. For this reason, maximum respect and tolerance towards everything that regards Muslim rites are essential. No jokes nor pranks on the Islamic faith's external 
manifestations are admissible since the utmost respect for religious beliefs and practices has to be guaranteed. Libyan women are usually kept away from public life, and the indigenous people are proudly jealous of them. Thus, everyone must abstain from any act towards them, which includes even looking at them. ${ }^{6}$

In this public statement of intent, General Caneva seems to be most concerned with respect for the local traditions and particularly for the Islamic religion. This statement's primary goal is to avoid unnecessary conflicts between the invading army and the local population, as the grip on the Libyan territory appeared to be all but secured. However, even if most definitely intended as a preventive measure, the circular order reveals three relevant issues. First, we find for the first time a reference to Islam as a defining category for the colonised population. Throughout the sources used in this article, religion often acts as a signifier of difference that justifies and complements racial hierarchisation between the Italian and Libyan populations. The terms 'Arab,' 'indigenous', 'Libyan', and 'Muslim' are often used interchangeably by the Italians as categories to signify the colonial Other. Such terms were used to connote the Arab and Berber Muslim populations, and the entirety of the sources analysed in this article directly refer to them as the primary source of concern for Italian administrators. Although Libya had a relatively large Jewish community, comprising 3.57 per cent of the total population (De Felice 1985, 62), the sources never mention Jewish women as a source of concern for the colonial policies regarding the intimate sphere of the colony's society. Second, by stressing 'the maximum respect and tolerance for Muslim rites', Caneva hints at the initial plan envisioned by the Italian colonialists of creating a system of indirect rule that could have taken advantage of the local elites' dissatisfaction with the secular and modernising Ottoman rule. ${ }^{7}$ Third, the order directly refers to Muslim women and their role within Libyan patriarchal society. Caneva gives the highest priority to his assumptions regarding the Libyans' patriarchal management of women's role in society and forbids Italian soldiers from even looking at Libyan women, let alone trying to engage in intimate relationships with them. As a matter of fact, 'Muslim authorities during the Ottoman period strictly policed the sexual behaviour of Muslim women' (Yeaw 2018b, 53), and Italians did not want to antagonise the Libyan population by unleashing the invading army's sexual violence on the rebellious local population. This danger was exemplified by the Orientalist discourse surrounding Libya and its populations before the territory's invasion. As argued by Yeaw (2018a, 69), the Italian imaginary on the colony framed it 'as a paradise for male conquest', a feminised frontier where Italian men could realise their sexual desires. The realisation of Italian men's fantasies had to be curbed at least discursively if the colonial administrations were to stabilise the just conquered territory. After all, Italians were attempting to create a class of complacent Libyan notables and, through them, 'incorporate natives into a state-enforced customary order' (Mamdani 2018, 18) while portraying themselves as respectful of local traditions, unlike the modernising Ottoman rule.

The Italian colonial administrators' will to crush the resistance and curry favour with the local population was still visible in 1916 when some top colonial administrators in Tripoli were still attempting to convey their goodwill and respect for Muslim tradition to the Libyan ruling class. In this excerpt from a dialogue between three Libyan notables (Farhad Bey, Ahmed Bey, and El Taieb Effendi) and two high ranking Italian officers (Castoldi and Caviglia) regarding the proclamation of a new mixed legislative commission for the city of Tripoli, it is possible to see the eagerness of the Italians to comply with the will of the Libyan elites and to prove themselves willing to respect the local traditions, particularly regarding the private sphere:

FARHAD BEY: AHMED BEY, EL TAIEB Eff.: We do as well. 
Cap. CASTOLDI:

AHMED BEY, EL TAIEB Eff.:

\section{Lt. Con. CAVIGLIA:}

It will be best if you state them at once.

Then it shall be best if we state everything minutely. ... Regarding customs, the inviolability of domicile, prohibition for Muslim women to marry men of other religions. Everything shall be done. Please provide us with a note with the names of the people to be appointed. ${ }^{8}$

In this excerpt, the emphasis on Muslim women's protection is put forward by the Libyan notables themselves, who state the prohibition for Muslim women to marry men of other religions as one of the main pillars of the colonial society they envision. Such a firm stance clarifies that initially, the will to maintain sexual segregation between colonisers and colonised was coming from the Libyan patriarchal ruling class. Simultaneously, the Italians were primarily interested in portraying themselves as respectful and almost protectors of Libya's religious traditions to strengthen their indirect rule plans through a complacent Libyan elite class. Nonetheless, besides the different motivations that moved the Libyan and Italian elites, this convergence of intents can arguably point to a similarity to Barrera's argument on a possible 'patrilinear convergence' $(2005,98)$ in Eritrea that worked to reinforce prohibitions of 'mixture' from both sides of the colonial divide. Unfortunately, the sources collected in Italian state archives do not clarify the stance of both parties on matters regarding 'mixed' descent, patrilineality and relative issues regarding citizenship and affiliation.

Another notable depiction of the official rhetoric that Italian administrators were attempting to portray concerning the respect of Libyan women is found in an order issued in 1918 by the colony's Governor Vincenzo Garioni to all the Italian civil servants who worked with the local population:

In some offices where some Muslim women show up, there is the habit of asking them to unveil their faces, which has created nuisances in the indigenous environment. Such behaviour is contrary to our political agenda since it violates an Islamic religious precept and constitutes an act of disrespect towards Muslim women, and it is in contradiction to the Caneva order of 1911. I hereby order that such practices be stopped and that State Offices comply with the orders promulgated over the years regarding the proper restraint towards the local population. ${ }^{9}$

The document acknowledges the habit of asking Muslim women to unveil their faces as a common practice, relying on the position of power that Italian civil servants held over the Libyan population, particularly over women. However, the governor's office warns that this practice is against Caneva's 1911 official order quoted at the beginning of this section. It was so because it 'constitutes an act of disrespect towards Muslim women' and is, therefore, 'contrary to our political action.'

The rhetoric of respect towards the Libyan population transpired in some policies related to Libyans' legal status. To quell the rebellion that was straining the Italian army after the end of the First World War, the Italian colonial administrators issued the Statuti, ${ }^{10}$ which granted a form of colonial citizenship, including civil and political rights, to all Libyans. Such a concession of rights to Libyans, which was never extended to their Eastern African counterparts that were considered a step down in the colonial hierarchy, was part of the colonial ideology regarding Libya of the Italian Liberal administration, which sought to portray its rule as enlightened and respectful.

Such attempts by colonising powers to portray themselves as respectful of local traditions, particularly regarding the private sphere of colonised societies, were not unique to the Italian context. For instance, after occupying Algeria in 1930, the French allowed the local population to practise 
the Islamic faith freely and attempted to portray themselves as protectors of the Islamic legal system for personal status issues related to the private sphere and the role of women within colonial society (Clancy-Smith 1998). As in Italian Libya, this discursive attitude was engineered to soften a section of the patriarchal local elites towards the colonial rule and show how the respect for traditions in private matters could balance the colonisers' modernising impulse regarding the public sphere. Simultaneously, the rhetoric and practice of 'respect' for local traditions were used to understand and frame modes of difference between colonisers and colonised. In particular, the Islamic personal status of Libyans was used by the Italians throughout their presence in the region as a sign of the incompatibility and backwardness of the Libyan population vis-à-vis the modernising Italian colonial rule and legal system.

In the first years of the Italian presence in Libya, as exemplified by the sources quoted in this section, the colonial administrators initially tried to convey a specific discourse related to the role of women within the newly created colonial environment, one that took into account the propaganda need to subdue a rebellious local population. However, as we will see in the next section from the analysis of the actual practices related to the regulation of sexuality within the colony, there was a definite and visible gap between the colonial discourse regarding the treatment of Libyan women and the actual regulatory practices. Even after 1922, which marked the rise of Fascism and the end of the season that saw attempts at establishing a system of indirect rule, the regulation of sexuality unfolded in two different and opposing paths: one that followed colonial discourses and one that followed colonial practices. To better understand such a gap, it is necessary to analyse the most relevant and diffuse intimate relationship between Italian men and Libyan women in the first two decades of Libya's colonisation: concubinage.

\section{Concubinage in a militarised colony: institutional discourse and practice}

When European identity and supremacy were thought to be vulnerable, in jeopardy, or less than convincing, concubinage came under more direct attack (Stoler 2002, 51).

This quote from Ann Laura Stoler's Carnal Knowledge exemplifies how colonial powers, at different times and places, shifted their regulatory attitude towards colonial concubinage according to their political needs: this also appears to be true for the Italian colonial context. The phenomenon of concubinage, or relationships more uxorio (of a marital nature) between Italian men and colonised women, was widespread in the Italian Eastern African colonies well before Italy started the colonisation of Libya, as studied in the mentioned researches of Iyob (2000), Sorgoni (1998) and Barrera (2002). Giulia Barrera focused on how the Italian colonial administrators dealt with the phenomenon of madamato (Barrera, 2004). Barrera argues that during the Liberal period, in colonial Eritrea, 'concubinage was regarded as a relationship that took place within the individual private sphere' and that therefore 'Italian authorities did little to regulate it, especially if the Italian individual involved was one of their peers: that is, a white, middle-class man' (Barrera 2004, 159). More than that, if we analyse archival sources of the time, we can see that colonial authorities, at the beginning of the Italian colonial rule in Eritrea, went as far as encouraging Italian officers to take concubines: 'General Baldissera had issued a circular letter telling officers that they should take a madama as soon as they landed in the colony., 11

Two reasons were leading Italian authorities to tolerate and even encourage forms of concubinage between Italian officers and Eritrean women. Firstly, if we follow Stoler's argument, Italian authorities might have considered their racial superiority not to be 'vulnerable' in such a context, and therefore did not interfere in the private lives of the Italian army officers. On a second note, concubinage represented a more 'dignified' form of sexual outlet for Italian officers, who, in 
this way, did not have to meddle with lower-class troopers in state-sanctioned brothels. As a confirmation of this, it is sufficient to read an excerpt from the memoirs of Alessandro Sapelli, an Italian officer deployed to Eritrea at the time:

[Officers] regarded it as harmful to their dignity to encounter their subordinates or other natives in the so-called horse-shoes, ${ }^{12}$ even if the natives were careful about vacating the premises when a white man entered them. So, the system of permanent relationships is initiated. The officer had a house built for the woman he had chosen [as a concubine]. He provided her with the necessary means for a decent living. (Sapelli 1935, 197)

Since colonial authorities widely tolerated, if not encouraged, forms of concubinage in colonial Eritrea during the Liberal period, it would be safe to assume that the same regulatory framework (or lack thereof) applied to the first years of colonisation of Libya, as there had been no change of political regime in the metropole between the two colonial enterprises. However, Italian authorities in Libya adopted a different approach regarding the regulation of social relations between the colonisers and the colonised: one that took into account the 'maximum respect and tolerance towards everything that pertains to Muslim traditions regarding their religious rites and women. ${ }^{13}$ Unlike Eritrea, Libya was far from being under the political control of Italian colonial authorities, who still regarded it as fundamental to portray the Italian rule as respectful of local customs, particularly regarding the private sphere. For these reasons, forms of concubinage in Libya were not regarded in the same way as they were in colonial Eritrea.

However, in colonial contexts, the official colonial rhetoric regarding the "proper restraint towards the natives' is rarely followed by the colonising troops' actual practice, particularly in sexual and affective relationships. Even if Italian colonial administrators established state-sanctioned brothels in Libya as soon as the colonisation began, Italian officers started to engage in forms of 'relationship of a conjugal nature,' or concubinage, soon after the first colonisation of Cyrenaican territories.

The colonial administrators, given the previously mentioned established colonial ideology regarding Libya, could not endorse a type of intimacy outside of the reach of state control, which could entail forms of affection, as was the case for Eritrea. On the other hand, however, they did not have access to any kind of official legislation prohibiting concubinage that they could refer to, as the only law addressing 'mixture' in Libya was the 1939 law that prohibited 'any type of relationship of a conjugal nature between metropolitan citizens and natives of Italian Africa. ${ }^{14}$ Although without a specific law to invoke, the colonial military administrators tried to maintain their official colonial rhetoric by sending circular letters to all officers in which they strongly condemned the practice of concubinage, even though without any substantial threat of criminal prosecution:

I have reason to believe that some officers who reside in the colony have hired indigenous women as
concubines by either allowing them to live in their own house, or by settling them in a dwelling nearby,
or by allowing them to still live with their families. Either way, they always agree on a fixed salary with
such women in exchange for a regular and exclusive working performance. The military discipline
regulation deems unacceptable any form of concubinage. Such prohibition must be followed even
more strictly in the colonial environment, for obvious reasons regarding the officers' dignity and
decorum, as much as regarding the efficacy of our current political action in the colony, making it
ever more pressing. ${ }^{15}$

This circular was sent out directly by the office of the Governor of Cyrenaica, General Giovanni Ameglio, on 24 February 1916. After underlining the spread of the concubinage phenomenon in the Cyrenaican colony, the circular letter stresses the prohibition of such practice in any military context, particularly in a colonial one, as written in the 'military discipline regulation' of the Italian army. 
However, regulations regarding the Italian military's discipline applied in different ways according to the context in which the army was operating. Indeed, forms of concubinage were allowed if not encouraged in Eritrea, where political concerns regarding the respect of the local private sphere were not as pressing as in Libya. Moreover, the circular stresses the importance of prohibiting such types of relationships as they would harm the 'efficacy of [the Italians'] political action in the colony.' This statement seems to be in line with the arguments made in the previous pages of this article. What was more pressing for the colonial administrators was not to enforce military discipline but to maintain the image of a colonising power that was careful about the local traditions regarding the private sphere. As the Sanusi rebellion was gaining momentum in the internal parts of Cyrenaica, the Italian governor could not afford to see the image of the colonisers damaged any further by the Italian officers' behaviour. For this reason, only three days after the emanation of the first circular, the governor thought to send an additional warning to the Italian army officers, one that stressed even further the importance of the respect of Libyan society's private sphere.

The Governor has become aware of the circular sent by this office on the 24th day of this month and wants to add an admonishment. His Excellency the Governor renews the absolute prohibition regarding all forms of concubinage and warns all the officers that he is set on taking substantial disciplinary measures against anyone who disobeys his orders. Moreover, he warns that he might take the extreme measure of referring the ones found guilty to the military tribunal on insubordination charges in case of disobedience. $^{16}$

The reiteration of the circular order, which in this second letter is undersigned by the governor in person, speaks of a total prohibition, leading to penal consequences if infringed. This severe and stark prohibition is striking not only for its contrast to the attitude towards the same forms of relationships that were still happening in those years in Eritrea but also because it seems to anticipate the harsh racist legislation implemented by the Fascist regime in the colonies from 1936 onwards.

Such a firm stance may also be connected to the previously quoted argument regarding the connection between concubinage regulation and the colonisers' imagined racial superiority vis-à-vis the Libyan population (Stoler 2002, 51). Italian authorities in Libya might not have been as confident in their racial superiority as they had been in Eritrea and therefore strived more carefully to separate the settlers and the local population. After all, Libya occupied a special place in Italian public discourse, being that 'fourth shore' soon to be juridically incorporated in the body politic of the nation itself (Segré 1972, 151). Moreover, the ambiguity regarding the racial difference between Italians and Libyans, with the latter being 'considered racially closer to their European masters than sub-Saharan Africans' (Casales 2020, 443), might have prompted the administrators to enforce stricter racial boundaries. Theoretical speculations aside, though, we can see here a discursive coherence of the Italian colonial administrators regarding the attitude to be taken in the Libyan territories toward the locals' private sphere and, particularly, Libyan women. As argued in the previous section, the exertion of patriarchal control over women's role was fundamental for the Libyan ruling class. The Italian administrators, striving to portray themselves as protectors of traditions so dear to the Libyan elites, created a discourse according to which unequal forms of sexual and/or affective relationships between Italian men and Libyan women were utterly unacceptable.

According to the sentences of the Italian Military Tribunals of Benghazi and Derna (the tribunals responsible for the troops deployed in Cyrenaica) preserved in the Italian Central State Archive, it appears that the threat pronounced by Governor Ameglio had no consequences. According to such archival records, no Italian officer ever faced prosecution on the grounds of 'insubordination' for not following the order on the prohibition of concubinage. It is unlikely 
that officers refrained from engaging in such relationships due to the governor's circular. However, it hints at a gap between the official rhetoric regarding concubinage prohibition and its enforcement.

Despite all the proclamations regarding respect of Muslim traditions and Libyan women, the toleration of forms of concubinage continued at least until the 1930s. This persistence meant that not even the rise of the Italian Fascist Party in metropolitan Italy in 1922 brought the enforcement of such prohibition. The rhetoric and the policies of the first years of Fascist rule in Libya closely resembled the ones of the Liberal period, and the colonial administrators kept trying to portray themselves as protectors of the Libyan population. Meanwhile, the Fascist administrators engaged in brutal military operations to repress the anti-colonial resistance, which was still particularly fierce in Cyrenaica. In the end, due to the military tactics of General Rodolfo Graziani - whose accomplishment would win him the title of vice-governor of the colony - coupled with the heavy use of illegal toxic weapons, the resistance was wholly crushed in both Tripolitania (1924) and Cyrenaica (1932).

\section{Regulating mabruchismo: new policy for a settler colony}

It is no coincidence that the first military punishments against forms of concubinage happened only in 1931, when the colony's militarisation slowly started to subside due to reaching the end of the repression of the Libyan resistance. The year 1932 would see the first enactment of the plans for Libya's mass demographic colonisation, which entailed the deportation of Cyrenaicans who inhabited fertile lands to concentration camps and the arrival of a large number of civilian settlers, including a considerable number of Italian women. ${ }^{17}$ The arrival of Italian women was pivotal in the Italian administrators' change of attitude. Indeed, in colonial settings, European women's presence always brings 'moral rearmament' (Stoler 2002, 60) as 'European women created a new and less flexible domestic colonialism exhibiting concern with the sexual accessibility and vulnerability of women, and with corresponding notions about the need for spatial and social segregation' (Beidelman 1982, 13). For these reasons, the need for stricter norms regarding the separation between Italians and Libyans would become more pressing, leading the colonial administrators to enforce for the first time the order issued by Governor Ameglio 15 years earlier.

In a circular letter addressed to all officers and dated 10 May 1931, the Chief of Staff of the Italian troops in Cyrenaica, Guglielmo Nasi, listed all the deportations from the colony carried out in the previous months of officers who had been deployed to those concentration camps in which Libyans were imprisoned. The circular had the clear intent of warning other officers of the consequences they could face if they engaged in the same behaviour. The command had dealt with two instances of concubinage with utmost severity:

The commander of a garrison in charge of a concentration camp for indigenous people found two officers engaged in romantic relationships with the concentration camp's indigenous women. Although he acted rightfully by ending them swiftly, he failed to report to his superior such facts, which are detrimental to the uniform's dignity because of an inappropriate indulgent spirit.

An officer, who was on duty in a concentration camp, fell into negotiations with an indigenous woman over the price to be paid for her daughter's favours, acting therefore in a manner that was detrimental to an officer's dignity. After paying the agreed sum, the officer kept the girl as a concubine, hosting her in a tent next to his. ${ }^{18}$

Another circular letter sent on the very same day and in the same way to all the officers stationed in Cyrenaica speaks of a very similar case: 
While on duty in a fort near a concentration camp under the Political Authority's control, an officer started negotiating with a captive indigenous man the price to be paid for his daughter's possession. He did this in a way that did not consider the fact that such behaviour was detrimental to the dignity of his officer's uniform. After paying the agreed sum, he obtained permission from the girl's father to take her to another place. However, he did not accomplish his will, as the officer's superior intervened, making him give the girl back in exchange for a portion of the money spent. ${ }^{19}$

In all three cases, the Chief of Staff deemed the officers highly irresponsible because by either engaging in, or attempting to engage in, or failing to report, forms of concubinage, they had put at risk the uniform's dignity. If it was an extreme 'detriment to the officers' uniform,' an act worthy of deportation from the colony, how is it possible that these are the first documented sanctions of this kind ever inflicted in Libya? Had officers only started to seek out concubines at the beginning of the 1930s, when first deployed to concentration camps? Were these indeed the first instances of concubinage in colonial Libya? We can find direct answers to these questions in another circular letter sent by General Rodolfo Graziani himself. It was 17 May 1932, only four months after the release of the official statement by Governor Badoglio that confirmed the end of the resistance in the last regions of Cyrenaica, when Graziani finally decided to clarify the actual practice regarding concubinage.

In little over one year, I have had to repatriate four officers (one of them recently) because they made financial transactions (or at least vigorously negotiated) to acquire indigenous women in order to keep them for themselves as concubines. This mabruchismo is one of the plagues that infested the colony. There are still some traces of it, or better still, some nostalgia; however, I intend to eradicate it. ... Of course, the sacrifice regarding the lack of women is required of the officer in the colonies. However, it is a sacrifice that, first of all, must not be exaggerated because it is not absolute; secondly, it is a known fact, and therefore it must be considered before the deployment, which, in any case, is not long. On their side, the command of the troops and the regional authority will ensure that they also meet these needs by establishing - where possible - additional brothels in all the places that still lack them. ${ }^{20}$

This letter is central to the understanding of the phenomenon of concubinage in Libya for several reasons. First, Graziani directly refers to the sanctions inflicted by Chief of Staff Nasi, and he claims to be the hand behind those punishments, implying, therefore, the gravity of the act since the vice-governor of the colony dealt with it in person. Secondly, he mentions the term mabruchismo, the expression Italians used to refer to concubinage relationships in Libya. This mention, alongside Graziani's characterisation of the phenomenon as 'one of the plagues that have infested the colony', confirms that the repatriated officers were not the first to have concubines in the colony, but only the first to be officially punished after countless officers who were not. Such development was due to the colony becoming less of a militarised, male-dominated space, which entailed the need for the Fascist administrators to be less tolerant towards 'mixed' cohabitation relationships. Third, Graziani's lead role in the crackdown of forms of anti-colonial resistance in both Libya and Ethiopia and the almost parallel prohibition of concubinage in both contexts point to the centrality of the man's role in the enforcement of Fascism's colonial racism. While his role in enforcing Minister Lessona's racial segregation policy in Ethiopia is already documented (Ceci 2019, 34), this article sheds new light on his centrality in this regard also in the Libyan context, highlighting a thread of connection between the two contexts. Finally, Graziani clearly states that the new practice regarding the crackdown of mabruchismo would have to be followed by opening an additional number of brothels for the officers who would have to sever the relationships with their concubines.

This last point shows us that not all forms of 'mixed' intimacies were deemed unacceptable, even by the increasing segregationist Fascist administration's standards. Non-racially-segregated prostitution was not only tolerated by the Italian colonial officials but regulated and encouraged as a viable alternative to the 'plague of concubinage'. European prostitutes had always constituted 
a minority in Libya (Salerno 1922, 55), and although Fascism pushed for more to work in the colonies (Pankhurst 1974, 177), their number was still relatively low (Yeaw 2018a, 74). For this reason, particularly in the proximity of isolated concentration camps, non-segregated prostitution remained the primary option to monitor the army members' sexuality in the colony. During the Liberal and early Fascist periods, as we have seen from the words of officer Sapelli regarding the Eritrean context, the use of brothels by the army was framed along class lines, as the 'dignity' of the officers could not be tarnished by using the same form of 'sexual outlet' as their subordinates (Sapelli 1935, 191). Graziani, however, by referring to the need for 'additional brothels' to curtail the phenomenon of concubinage, directly negates that the same was valid for Italian Libya as well, at least for the new settler colony that the Fascist administrators were trying to build. For the Cyrenaican colonial government, concubinage was a worse option than non-segregated prostitution, state-controlled or not.

The Fascist administrators' dislike of concubinage among other forms of 'mixed' intimacies is evident from the analysis of the first official regulation of 'mixed' relationships in the Italian empire, which specifically targeted 'mixture' between Italians and Eastern Africans. ${ }^{21}$ Amid the racist ideological shift that followed the empire's proclamation, the Fascist government promulgated the law 1937 n.880 with the clear intent of curtailing forms of concubinage and not any other form of sexual relationships between colonisers and 'Eastern African natives'. In the debate that ensued among Fascist jurists on the ratio legis behind such prohibition, initially, most of them agreed that it could find its basis in the need to protect the racial superiority of the colonisers from racial promiscuity, which could, in turn, lead to the birth of meticci or 'mixed' offspring (De Napoli 2009, 77). The jurist Berlindo Giannetti, however, pointed to the fallacy of such an argument and criticised the law itself by stating that the birth of 'mixed' children was possible with any sexual relationship between Italians and colonial subjects and that, therefore, with a prohibition of concubinage alone, 'the lamented inconveniences regarding the possible creation of mixed children persist' (Giannetti 1939, 164) Once again, we can see a gap in the representation of colonial ideology and its practical enforcement. No punishment was inflicted on Italian citizens for engaging in other forms of 'mixed' intimacies, hinting that what was really at stake was not the 'mixed' sexual act and its possible offspring, but the possibility of the emotional connotation that forms of cohabitation could develop. As written by the historian Olindo de Napoli $(2009,78)$ :

[The law 1937 n. 880] was the prescription for the indigenous woman's sole objectification: she could not receive or give affection, but she had to be used as an object. This was because, within the constraints of colonial life, while waiting for a more significant influx of Italian women to reach the colony and with the absence of brothels with white women only, the regime understood that the Italian male citizens residing in the colony needed a sexual outlet. Therefore, there was no punishment if the indigenous woman was treated as an object, as a mere vehicle to achieve sexual gratification.

The issue at stake is the prohibition of possible affection between two differently racialised subjects, or between a superior subject and a racialised object. The intent to portray the colonised population as inferior by the Fascist administrators, with the final goal of achieving complete racial segregation in the Eastern African colony, could not allow the public presence of affective relationships between the two main racial groups in the colony.

Such analysis of the actual ratio legis behind the promulgation of the law $1937 \mathrm{n} .880$ can also be applied to the Libyan context and the circular of Rodolfo Graziani quoted earlier in this section. The only acceptable forms of 'mixed' intimacy in Cyrenaica, a colony that was transitioning from a militarised space to a segregated, settler colony, were the ones that kept colonisers and colonised on two distinct, hierarchical levels. Graziani is clear: the colonial administrators were willing to build one brothel for every military outpost of the colony, but forms of concubinage that could lead to 
emotionally charged relationships were no longer tolerated in any way. The days in which the Liberal administrators wanted to discursively reprimand forms of concubinage while tolerating the actual practice were long gone: for the new Fascist colony, ideology and practice had to coincide. After all, the Fascist regime was in the process of increasingly characterising the Italian national identity as chauvinistic and racially charged: anything that could tarnish the sense of racial superiority of the Italians, particularly in the colonies, had to be eradicated in its entirety.

What has been argued in these pages does not imply that all concubinage relationships in Libya had in them the seed of affection or even love, but only that the Fascist administrators wanted to take no chances in that regard. Although not recordable through the voices of Libyan women, which are absent from the Italian archives, the exploitative character of concubinage in Libya is clear from the official sources of these archives. We know from the analysed sanctions to the officers that some of the women were sold by their parents to the Italians; others must have been kidnapped; others again might have been former prostitutes or slaves looking for more economic security. We can assume that all these reasons, or a combination of them, might have led them to leave their families, much more than love or affection for the Italian officers who kept them as concubines, although that might have been possible as well. Even if we have no direct sources on how Libyan communities in which the concubines lived perceived the phenomenon of mabruchismo, we can assume that it was not well seen, particularly from the efforts that the Liberal colonial administration made in the 1910s and early 1920s to reprimand it discursively. Moreover, we know that in neighbouring Algeria, qadis (or shar'ia law judges) punished women who engaged in sexual relationships with Europeans (Dunne 1994, 27) and that Muslim women could experience violence from community members if they violated communal boundaries (Yeaw 2018a, 89). Similar experiences might have happened to Libyan concubines as well, who, pushed most likely by economic necessity or coercion, had to face the violence of both the colonisers' objectification and the local communities' patriarchal social hierarchies.

\section{Conclusion}

This article has described the regulatory attempts by Italian administrators of a form of 'mixed' intimacy that has been mostly left out of the academic debate on Italian colonial history. Although not as frequent as its counterpart in the Eastern African colonial context, mabruchismo was a relevant form of colonial intimacy that played a vital role in the development of the power relations between the Italian colonising elites and the Libyan population. The practice appears to have resembled the mentioned madamato prevalent in the Italian Eastern African colonies. Moreover, the reference to payments to the parents of the women involved suggests a form of temporary marriage agreement along the lines of the Eastern African demoz (Sòrgoni 1998). Future comparative research on the two practices might help to fully assess the continuities and discontinuities between them. This work aims to be a first step in filling the gaps of scholarly knowledge on concubinage in colonial Libya, one that directly addresses the top-down regulatory approach of the Italian colonial government and its political motivations. Future avenues for research on this topic should focus on the 'mixed' children born to these relationships and on Libyan women's direct experiences. Very little is known about these topics in the Libyan context, although Deplano's (2017) recent works on the former and Yeaw's (2018a) on the latter hint at promising avenues of further research. Notwithstanding the still unclear implications of mabruchismo, the analysed sources were able to show how regulations (or lack thereof) of concubinage in the Libyan context were highly indicative of the political agenda of the colonising power and of how the two sides of the colonial encounter negotiated power over the private sphere of the colony's population. 
Initially, the Italian administrators' apparent will to avoid concubinage was engineered as a discursive tool to implement a form of indirect rule that could have worked only with a compliant local elite class. At the same time, however, Italian officers claimed the necessity to have a sexual outlet other than the non-segregated prostitution envisioned for the lower-class troops. This context created an evident gap between the Italians' discursive stance and the actual regulation of colonial concubinage. Within such a gap, Italians considered Libyan women as tools to balance the colonisers' political agenda with the colonial imperative to create a class-based sexual outlet for the different ranks of the colonial army. Although discursively reprimanded as an affront to both the dignity of the army's uniform and the local patriarchal traditions, concubinage was never regulated until the colony became a militarised space devoid of a significant settler population.

By the early 1930s, with the resistance subsiding and the demographic colonisation plans finally being enacted, the stance of the Fascist administration shifted considerably. As the colony was set to include thousands of Italian settlers, it was not acceptable to maintain an ambiguous gap between the official discourse on colonial concubinage and its regulation. Cases of mabruchismo in the army started being punished more swiftly. At the same time, the spatial segregation between the colonised population and the settlers became starker by the year, culminating with racist legislation of 1937 prohibiting any 'mixed' relationship in the empire. Simultaneously, however, non-segregated prostitution remained a valuable solution for providing a sexual outlet to the army officers deployed away from settler areas of the colony, testifying to the instrumentality of the prohibition enacted by the Fascist elites. Regulations (or lack thereof) on colonial concubinage, as much as non-segregated prostitution, always followed the specific political projects of the colonising elites, who used sexuality and intimacy as focal points with which to structure colonial power along intersectional lines.

The Libyan women involved in relationships of mabruchismo were dangerous to the racial purity of Italians because they could potentially transcend the objectifying boundaries inscribed on their bodies by the colonisers. In a segregated colony, where the plan of characterisation of Italy's national identity as signified by race, enacted by the regime, was central to the organisation of colonial life itself, a humanisation of the colonised woman was unacceptable. Their racialised and objectified bodies, and the act of 'mixing' with Italians who were increasingly characterised as white by the Fascist regime, represented a threat to the very ways in which Fascism was organising epistemological categories related to concepts of race, nation, gender, and class. Such cases of 'mixed' relationships and their regulation represent a pivotal access point to the analysis of colonial power and its effect on epistemological processes that organised Italian colonial societies.

\section{Acknowledgements}

This research was funded by the European Research Council, as part of the project 'Regulating Mixed Intimacies in Europe (EUROMIX)' (grant number 725238). I would like to thank my family, my partner and my research team for the help and support they provided for me during my research. I would particularly like to thank the PI of the EUROMIX project, Professor Betty de Hart, and my supervisor Dr Elena Zambelli, for their helpful comments. Moreover, I would like to thank the co-editor of the journal, Dr Mammone, and the anonymous peer reviewers for their valuable criticisms on this article's earlier drafts.

\section{Notes on contributor}

Andrea Tarchi holds an MSc in Cultural Anthropology from the University of Utrecht, and he is a PhD candidate in the Migration Law section of the Vrije Universiteit Amsterdam. He is part of the EUROMIX research 
project, a multidisciplinary project that studies the regulation of 'mixture' ('inter-racialised' sex, relationships and marriage) in Europe's past and present.

\section{Notes}

1. ASSME (Archivio Storico Stato Maggiore Esercito), R.D. 1 maggio 1924, n. 983, N-11, busta 4025, 1 maggio 1924.

2. All translations from Italian are mine.

3. Even if the names 'Libya' and 'Libyans' were used to indicate the colonial territories and their populations only after Italo Balbo unified Tripolitania, Cyrenaica and Fezzan in 1934, in this article they will be used as encompassing terms to indicate all populations and territories under Italian rule in the region.

4. The terms 'mixture' and 'mixed' are conceptualised in this article as the coupling of two individuals who are socially understood as belonging to two differently perceived 'races' at a specific time and place. The single quotation marks are used to emphasise the social construction character of race and hence of its 'mixing'.

5. The term mabruchismo had its origin in the Arabic name 'Mabroukah', one of the most common first names given to Libyan women.

6. ASSME, Norme di contegno verso la proprietà, la religione, gli usi ecc. Degli indigeni, L-8, busta 220, 9 ottobre 1911.

7. For a thorough analysis of the first Italian colonial administrations' efforts at establishing a form of indirect rule over Libya, see Ryan 2012.

8. ASMAI (Archivio Storico Ministero Africa Italiana) Vol. II, Pos. 126.1. Colloquio avvenuto tra ufficiali Italiani e delegati Arabi in Tripoli, 1916.

9. ASMAI Vol. II, Donne mussulmane, prot. N. 7780, Pos. 114.1, 29 settembre 1918

10. Regio Decreto (R.D.) 1 giugno 1919 n. 931 che approva le norme fondamentali per l'assetto della Tripolitania, in Raccolta ufficiale delle leggi e dei decreti del Regno d'Italia, 1919, vol. 2, p. 1844-1852 and R.D. 31ottobre n. 2401 che approva le norme fondamentali per l'assetto della Cirenaica, ivi, vol. 6.1, p. 5702-5712.

11. Quoted in Barrera 2004, 161.

12. The state-sanctioned brothels in Eritrea were colloquially referred to as horse-shoes, given their shape.

13. ASSME, Norme di contegno verso la proprietà, la religione, gli usi ecc. Degli indigeni, L-8, busta 220, 9 ottobre 1911.

14. Law 1939-XVII n. 1004 'Sanzioni penali per la difesa del prestigio di razza di fronte ai nativi dell'Africa Italiana'.

15. ASMAI Vol. II, Pos. 146.1. Concubinaggio. 24 Febbraio 1916.

16. ASMAI Vol. II, Pos. 146.1. Concubinaggio. 27 Febbraio 1916.

17. For a thorough analysis of the different stages of the Italian demographic colonisation of Cyrenaica, see Cresti 2011.

18. ACS (Archivio Centrale dello Stato), Fondo Rodolfo Graziani, Busta 11, Circolare 4189, 10 Maggio 1931.

19. ACS, Fondo Rodolfo Graziani, Busta 11, Circolare 4190, 10 Maggio 1931.

20. ACS, Fondo Rodolfo Graziani, Busta 11, Circolare 2935, 17 Maggio 1932.

21. R.D. n. 880 of 1937, which stated that 'The Italian citizen who, in the territory of the Kingdom or of the Colonies, engages in a relationship of conjugal nature with a subject person of Italian East Africa or a foreigner belonging to a population that has traditions, customs or juridical and social concepts similar to those of the subjects of Italian East Africa, is punished with imprisonment from one year to five years.'

\section{References}

Ballhatchet, K. 1980. Race, Sex, and Class Under the Raj: Imperial Attitudes and Policies and Their Critics, 1793-1905. London: Weidenfeld and Nicolson.

Barrera, G. 2002. 'Colonial Affairs: Italian Men, Eritrean Women, and the Construction of Racial Hierarchies in Colonial Eritrea (1885-1941)'. PhD thesis., Northwestern University, Il. 
Barrera, G. 2004. 'Sex, Citizenship and the State: The Construction of the Public and Private Spheres in Colonial Eritrea'. In Gender, Family and Sexuality: The Private Sphere in Italy 1860-1945, edited by P. Wilson, 157-72. London: Palgrave Macmillan.

Barrera, G. 2005. 'Patrilinearity, Race, and Identity: The Upbringing of Italo-Eritreans during Italian Colonialism'. In Italian Colonialism, edited by R. Ben-Ghiat and M. Fuller, 97-108. New York: Palgrave Macmillan.

Beidelman, T. 1982. Colonial Evangelism: A Socio-Historical Study of an East African Mission at the Grassroots. Bloomington: Indiana University Press.

Bryder, L. 1998. 'Sex, Race, and Colonialism: An Historiographical Review'. The International History Review 20 (4): 806-22.

Campassi, G. 1987 'Il madamato in Africa Orientale. Relazioni tra italiani e indigene come forma di aggressione coloniale'. Miscellanea di storia delle esplorazioni (12): 219-60.

Casales, F. 2020. 'Purezza e meticciato: The Italian Colonial Novel and the (Re)production of Italian Whiteness'. Modern Italy 25 (4), 439-54.

Ceci, L. 2019. 'Separare e punire: il razzismo nell'Impero fascista'. In Le leggi razziali. Prima e dopo la Shoah: modelli, pratiche ed eredità, edited by IHRA Italian Chairmanship 2018, 25-38. Rome: Fondazione per le Scienze religiose.

Clancy-Smith, J. 1998. 'Islam, Gender and Identities in the Making of the French Algeria, 1830-1962'. In Domesticating the Empire: Race, Gender, and Family Life in French and Dutch Colonialism, edited by J. Clancy-Smith and F. Gouda, 154-74. Charlottesville, VA: University of Virginia Press.

Cresti, F. 2011. Non desiderare la terra d'altri: la colonizzazione italiana in Libia. Rome: Carocci Editore. De Felice, R. 1985. Jews in an Arab Land: Libya, 1835-1970. Austin: University of Texas Press.

De Napoli, O. 2009. La prova della razza. Cultura giuridica e razzismo in Italia negli anni Trenta. Florence: Le Monnier.

Deplano, V. 2017. La Madrepatria è una terra straniera. Libici, eritrei e somali nell'Italia del dopoguerra (1945-1960). Florence: Le Monnier.

Dunne, B. 1994. 'French Regulation of Prostitution in Nineteenth-Century Colonial Algeria'. The Arab Studies Journal 2 (1): 24-30.

Giannetti, B. 1939. 'Diritto penale e difesa della razza (III)'. Rassegna sociale dell'Africa Italiana II (9).

Hyam, R. 1986. 'Concubinage and the Colonial Service: The Crewe Circular (1909)'. The Journal of Imperial and Commonwealth History, 14 (3): 170-86.

Iyob, R. 2000. 'Madamismo and Beyond: The Construction of Eritrean Women'. Nineteenth Century Contexts 22 (2): 217-38.

Mamdani, M. 2018. Citizen and Subject: Contemporary Africa and the Legacy of Late Colonialism. Princeton: Princeton University Press.

McKinley, M. 2014. 'Illicit Intimacies: Virtuous Concubinage in Colonial Lima'. Journal of Family History 39 (3): 204-21.

Ming, H. 1983. 'Barracks-Concubinage in the Indies, 1887-1920'. Indonesia 35: 65-94.

Pankhurst, R. 1974. 'The History of Prostitution in Ethiopia'. Journal of Ethiopian Studies 12 (2): 159-78.

Ponzanesi, S. 2012. 'The Color of Love: Madamismo and Interracial Relationships in the Italian Colonies'. Research in African Literatures 43 (2): 155-72.

Ryan, E. 2012. Italy and the Sanusiyya: Negotiating Authority in Colonial Libya, 1911-1931. PhD thesis, Columbia University.

Salerno, L. 1922. La polizia dei costumi a Tripoli, con cenni storici sulla prostituzione. Lugo: Tipografia Editrice Trisi.

Sapelli, A. 1935. Memorie d'Africa (1883-1906). Bologna: Nicola Zanichelli Editore.

Scott, J. 1986. 'Gender: A Useful Category of Historical Analysis'. The American Historical Review 91 (5): $1053-75$.

Segré, C. 1972. 'Italo Balbo and the Colonization of Libya'. Journal of Contemporary History 7 (3): 141-55.

Sòrgoni, B. 1998. Parole e corpi: antropologia, discorso giuridico e politiche sessuali interrazziali nella colonia Eritrea: 1890-1941. Naples: Edizioni scientifiche Italiane. 
Stoler, A. 2002. Carnal Knowledge and Imperial Power: Race and the Intimate in Colonial Rule. Berkeley: University of California Press.

Trento, G. 2011. 'Madamato and Colonial Concubinage in Ethiopia: A Comparative Perspective'. Aethiopica 14: 184-205.

Yeaw, K. 2018a. Women, Resistance and the Creation of New Gendered Frontiers in the Making of Modern Libya, 1890-1980. PhD thesis, Georgetown University.

Yeaw, K. 2018b. 'Gender, Violence and Resistance Under Italian Rule in Cyrenaica, 1923-1934.' The Journal of North African Studies 23 (5): 791-810.

Yeaw, K. and B. Spadaro. 2020. Women in the Modern History of Libya: Exploring Transnational Trajectories. New York: Routledge.

\section{Italian summary}

Questo articolo analizza gli atteggiamenti delle amministrazioni liberali e fasciste nei confronti del concubinato coloniale durante gli anni della repressione della resistenza anticoloniale nella Libia italiana (1911-1932). Conosciuto anche come mabruchismo, il concubinato in Libia aveva aspetti in comune con la sua controparte nell'Africa Orientale Italiana, con ufficiali italiani di classe medio-alta che costringevano donne colonizzate a impegnarsi in relazioni intime. Durante i primi venti anni di colonizzazione del territorio, l'amministrazione militare della colonia assunse una posizione ambigua riguardo alla pratica, condannandola discorsivamente per ingraziarsi le élite locali mentre la permetteva in via ufficiosa al fine di fornire relazioni sessuali sicure ai suoi ufficiali. Quando la resistenza fu sconfitta all'inizio degli anni ' 30 e l'amministrazione fascista iniziò i suoi piani di colonizzazione demografica, il concubinato coloniale fu proibito in quanto fuori luogo in una colonia segregata secondo criteri razziali. Questo articolo utilizza un'analisi di fonti d'archivio istituzionali per tracciare il quadro normativo che plasmò la vita delle donne libiche e degli ufficiali italiani coinvolti in relazioni di concubinato in una società coloniale in continuo cambiamento. Gli sforzi delle amministrazioni coloniali per regolamentare il concubinato testimoniano il ruolo cruciale che le donne libiche e le relazioni razziali "miste" giocarono nel plasmare categorie di razza, classe e genere nel contesto coloniale italiano. 